\title{
İki Farklı Düşük Yoğunluklu Polietilen (LDPE) Plastik Atığın Bitüm Modifikasyonunda Kullanımı
}

\author{
İremgül Bektaş ${ }^{1}$, Erkut YALÇIN ${ }^{1^{*}}$, Özge Erdoğan YAMAÇ ${ }^{1}$, Mehmet YILMAZ $^{1}$ \\ ${ }^{1}$ İnşaat Mühendisliği Bölümü, Mühendislik Fakültesi, Fırat Üniversitesi, Elazı̆̆g, Türkiye \\ *1 erkutyalcin@firat.edu.tr
}

(Geliş/Received: 25/01/2021;

Kabul/Accepted: 15/02/2021)

\begin{abstract}
Özet: Bu çalışmada, en önemli çevresel sorunlardan birini çözmek ve düşük maliyetli malzemelerle bitüm performans özelliklerini geliştirmek için atık plastiklerden olan düşük yoğunluklu polietilen (LDPE) kullanılmıştır. Çalışmada kullanılan 2 farklı LDPE 4 farklı oranda (\%1, \%2, \%3 ve \%4) ilave edilerek modifiye bitümler hazırlanmıştır. Saf ve modifiye bitümlere penetrasyon, yumuşama noktası, iki farklı sıcaklıkta $\left(135^{\circ} \mathrm{C}\right.$ ve $\left.165^{\circ} \mathrm{C}\right)$ dönel viskozite deneyleri uygulanmıştır. LDPE katkılarının kullanılması ile saf bağlayıcıya göre penetrasyon değerlerinin azaldığı, yumuşama noktası ve viskozite değerlerinin ise arttığı tespit edilmiştir. Yapılan analizler sonucunda LDPE-A (L1) katkısının LDPE-B (L2) katkısına göre daha olumlu sonuçlar verdiği belirlenmiştir. L1 modifiyeli bitümlerin L2 modifiyeli bitümlere göre daha düşük penetrasyon değerine sahip olduğu belirlenmiştir. Ayrıca L1 bağlayıcısının L2 bağlayıcısına göre tüm katkı içeriklerinde daha yüksek viskozite değerlerine sahip olduğu belirlenmiştir. Katkı içeriği arttıkça viskozite değerleri de artmaktadır.
\end{abstract}

Anahtar kelimeler: Bitüm, Modifikasyon, LDPE, Dönel Viskozimetre

\section{The Use of Two Different Low Density Polyethylene (LDPE) Plastic Wastes in Bitumen Modification}

Abstract: In this study, low density polyethylene (LDPE) was used in waste plastics to solve one of the most important environmental problems and to improve bitumen performance properties with low cost materials. Modified bitumens were prepared by adding 2 different LDPE' used in the study in 4 different proportions ( $1 \%, 2 \%, 3 \%$ and $4 \%$ ). Penetration, softening point and rotational viscosity tests at two different temperatures $\left(135^{\circ} \mathrm{C}\right.$ and $\left.165^{\circ} \mathrm{C}\right)$ were applied to pure and modified bitumens. Using LDPE additives, it was determined that the penetration values decreased, the softening point and viscosity values increased compared to the pure binder. As a result of the analysis, it was determined that the LDPE-A (L1) contribution gave more positive results than the LDPE-B (L2) contribution. It was determined that L1 modified bitumen has a lower penetration value than L2 modified bitumen. In addition, it was determined that L1 binder has higher viscosity values in all additive contents compared to L2 binder. As the additive content increases, the viscosity values also increase.

Key words: Bitumen, Modification, LDPE, Rotational Viscometer

\section{Giris}

Çevre sorunlarının en önemlilerinden biri, yeryüzünde her geçen gün artan atık maddelerdir. Atık maddelerden biri olan plastik atığı, tüm dünyada son derece önemli bir sorun haline gelmiştir. Plastik atıklarının en büyük payını ambalaj atıkları oluşturmaktadır [1]. Avustralya'da yapılan bir Plastik Geri Dönüşüm Anketi, 2016-2017 yıllarında toplam plastik tüketiminin 3.513.100 ton olduğunu ve yalnızca 415.200 tonun geri dönüştürüldüğünü ortaya koymuştur [2]. Çin'deki plastik üretimi ve kullanımının, son yıllarda yılda 30 milyon tonun üzerinde atık plastiğe yol açtı̆ğ belirlenmiştir [3]. 2010 yılında 192 kıyı ülkesinde 275 milyon ton plastik atık üretildiği ve bunlardan 4,8 ila 12,7 milyon tonun okyanusa karıştığı tahmin edilmektedir [4]. Avrupa Birliği'nde plastik atık yönetimi gelişmesine rağmen, plastik atıkların çoğu (\%41'i) yakılmaya gönderilmekte ve plastik atıkların yaklaşık \%30'u geri dönüştürülmektedir [5]. Amerika Birleşik Devletleri Çevre Koruma Ajansı'na (EPA) göre, ABD'de 2017 yılında 35.370 ton plastik üretildi, bunun sadece \%8,4'ü (2960 tonu) geri dönüştürüldü ve \%75,8'i (26.820 tonu) ise gömüldü (Çevre Koruma Ajansı (EPA)). Düzenli depolama alanlarından toplanan sızıntı suyu örneklerinden 10 ile $100 \mathrm{~mm}$ arasında mikroplastiklerin mevcut olduğu tespit edildiğinden atık plastik malzemeler çevreyi ve halk sağlığını tehdit etmektedir [6]. Bu, depolama sahasının plastiklerin nihai çukuru olmadığını, ancak içme suyu kalitesine ve diğer su kaynaklarına tehdit oluşturan potansiyel bir mikro plastik kaynağı olduğunu göstermektedir. Hwang ve arkadaşları, polipropilen mikroplastik partiküllerin hücrelerle

\footnotetext{
* Sorumlu yazar: erkutyalcin@firat.edu.tr. Yazarların ORCID Numarası: ${ }^{1} 0000-0003-4933-8574,{ }^{1} 0000-0002-6389-4211,{ }^{1} 0000-0003-$ 0535-891X, ${ }^{1} 0000-0002-2761-2598$
} 
doğrudan temasının, hücrelere doğrudan toksisite yerine bağışıklık hücrelerinden sitokin üretimini indükleyerek sağlık sorunlarına neden olma potansiyeline sahip olabileceğini belirlemişlerdir [7].

Atık plastik, son birkaç yıldır çok dikkat çeken malzemelerden biridir [8,9]. Bununla birlikte, ABD'deki atık plastik geri dönüşüm oranı, geri dönüşüm oranlarını $\% 30$ ile $\% 60$ arasında bildiren diğer ülkelerin çok altındadır. Japonya ise \%78 ile en yüksek geri dönüşüm oranına sahiptir [10]. Plastik atık karışımlar karmaşık yapısı ve verimsiz mekanik geri dönüşümü nedeniyle geri dönüştürülmesi zor malzemelerdir. Avustralya, gelişmekte olan ülkelere atık göndermek yerine, Avustralya'nın atık üretimine önemli bir katkıda bulunan geri dönüştürülmüşs plastik kullanma alternatifini geliştirmek için proaktif adımlar atmaktadır [2]. Ayrıca ABD'de de atık plastikleri kullanmak için yeni alternatifler aranmaktadır. Çin ve Hindistan'da ise atık plastiklerin ithal edilmesi yasaklanmıștır [11].

Plastik kullanımının azaltılması, doğrudan atık plastiği azaltmanın en iyi yolu olabilir. Örneğin, tek kullanımlık plastikleri yasaklayarak sıfır atı̆̆a doğru ilerlemek için bir perspektif önerilmiştir [12]. Bu yasağın yerine getirilmesi ve uygulanması zor olabilir, bu nedenle plastik atık sorununu azaltmak için başka seçenekler aranmalıdır. Araştırmacılar ve mühendisler, atık plastik malzemeleri değerlendirerek inşaat altyapılarında kullanılabilecek ahşap plastik kompozitler [13], beton bloklar [14] ve harçlar [15, 16] üretmek için çalışmalar yapmaktadır. Ramli ve Tabassi yapmış olduğu çalışmada, polimer modifiyeli harçların geleneksel harç karışımlarından daha iyi mühendislik özellikleri sergilediğini bulmuşlardır [17]. Arulrajah ve arkadaşları plastik granüllerin, temel dolgu malzemesi olarak kullanılan ezilmiş tuğla ve geri kazanılmış asfalt kaplama (RAP) atıkları ile birlikte kullanılma olasıılığını araştırmıştır [18].

Bitümlü kaplamalarda atık malzemelerden yararlanmak son yıllarda büyük önem arz eden çevreci bir yaklaşımdır. Bitüm, kaplamada en çok kullanılan bağlayıcıdır ve yenilenemeyen bir kaynak olan petrolden elde edilir [9]. Bir yandan araştırmacılar çevreci çalışmalar kapsamında atık motor yağı, yemeklik yağ, domuz gübresi ve kahve telvesi gibi çeşitli atıklardan faydalanmaktadır. Bu durum da şüphesiz zararlı çevresel etkileri ve işlenmemiş malzeme tüketimini azaltabilir. Öte yandan mühendisler, geri dönüştürülmüş malzemeler içeren bu tür kaplama altyapısının performanslarının geri dönüştürülmüş̧ malzeme içermeyenler kadar iyi olduğu kanıtlanmadıkça, büyük miktarda geri dönüştürülmüş malzeme kullanımını savunmakta tereddüt etmektedir. Yollarda çeşitli atık polimerlerin kullanımı ile ilgili birçok çalışma bulunmaktadır [19, 20]. Bununla birlikte literatürde, çeşitli dozajlarda ve tiplerde geri dönüştürülmüş plastikler içeren asfalt kaplamaların performansını tam olarak anlamada boşluk vardır.

Düşük yoğunluklu polietilen (LDPE), yüksek sıcaklıkta tekerlek izi direncini iyileştirmek ve sıcaklık duyarlılığını önemli ölçüde azaltmak için genellikle bitüm modifikasyonunda kullanılmaktadır. Bu çalışmada, bitüm modifikasyonunda iki farklı kimyasal içeriğe sahip düşük yoğunluklu polietilen (LDPE) kullanılmasının bitümlü bağlayıcıların fiziksel özelliklerine olan etkisi araştırılmıştır. İki farklı LDPE bağlayıcı 4 farklı (\%1, \%2, $\% 3$ ve \%4) oranda saf bitüme eklenmiştir. Saf ve modifiye bitüme penetrasyon, yumuşama noktası ve dönel viskozite deneyleri uygulanmıştır.

\section{Materyal ve Metot}

Çalışmada saf bağlayıcı olarak TÜPRAŞ Batman rafinerisinden temin edilen B 50/70 sınıfı bitüm kullanılmıştır. Saf bağlayıcı iki farklı fiziksel özelliklere sahip LDPE katkısı ile modifiye edilmiştir. Çalışmada kullanılan düşük yoğunluklu polietilen (LDPE) Adanus Plastik şirketinden temin edilmiştir. Bu çalışmada 2 farklı kimyasal bileşene sahip LDPE 4 farklı oranda (\%1, \%2, \%3 ve \%4) saf bitüme ilave edilerek hedef bağlayıcılar hazırlanmıştır. LDPE katkılı bitüm hazırlama işlemi aşağıdaki sıralamaya göre yapılmıştır.

- İlk önce saf bitüm $180 \pm 5^{\circ} \mathrm{C}$ 'deki etüvde 30 dakika ssıtılarak akışkan hale getirildi.

- Akışkan hale getirilen bitüm 500 gram olacak şekilde karıştırııının metal haznesine döküldü.

- Homojen 1sıl kaynağı oluşturmak için metal hazneye dökülen bitümün $180 \pm 5^{\circ} \mathrm{C}$ koşullandırılan isıtıcı kaynağı üzerindeki ısıl gömleğin içerisine bırakıldıktan sonra 1sıtıcı $180 \pm 5^{\circ} \mathrm{C}$ 1sıl dengesini sağlayana kadar bekletildi.

- LDPE, bitümün ağırlığınca belirlenen yüzdelerde sıcak bitümün içerisine döküldü.

LDPE içeren bitümler, 60 dakika boyunca 1000 devir/dakika hızla çalışan mekanik karıştıııcı ile karıştırılarak hazırlanmıştır [20] (Şekil 1). Saf ve LDPE içeren bağlayıcıların çalışmada kullanılan kısaltmaları Tablo 1'de verilmiştir. LDPE katkılarının fiziksel özellikleri Tablo 2'de verilmiştir. 


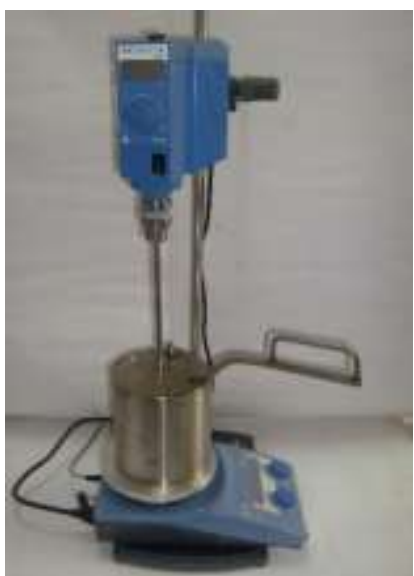

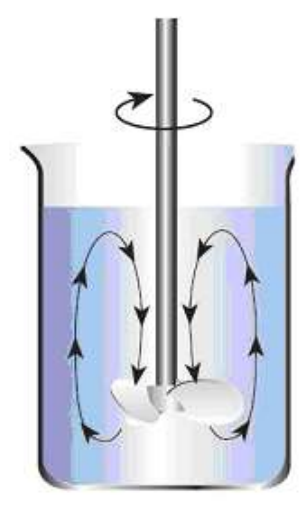

(a)

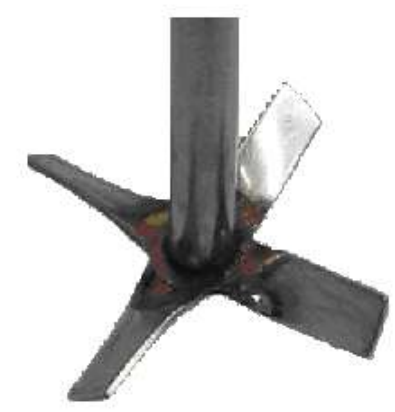

(b)

Şekil 1. Laboratuvar tipi karıştırma cihazı; (a) karıştırma etkisi ve (b) dört bıçaklı karıştırıcı

Tablo 1. Çalışmada bitümlü bağlayıcılar için kullanılan kısaltmalar

\begin{tabular}{lccccc}
\hline \multirow{2}{*}{ Katkı Adı } & \multicolumn{5}{c}{ Düşük Yoğunluklu Polietilen Katkı İçeriği (\%) } \\
\cline { 2 - 6 } & $\mathbf{0}$ & $\mathbf{1}$ & $\mathbf{2}$ & $\mathbf{3}$ & $\mathbf{4}$ \\
\hline Düşük yoğunluklu polietilen A (L1) & \multirow{2}{*}{ Saf } & L1-1 & L1-2 & L1-3 & L1-4 \\
Düşük yoğunluklu polietilen B (L2) & & L2-1 & L2-2 & L2-3 & L2-4 \\
\hline
\end{tabular}

Tablo 2. LDPE katkılarının fiziksel özellikleri

\begin{tabular}{lcc}
\hline \multicolumn{1}{c}{ Özellikler } & L1 & L2 \\
\hline Özgül ağırlığ $1\left(\mathrm{~g} / \mathrm{cm}^{3}\right)$ & 0,913 & 0,916 \\
Gerilme kuvveti $(\mathrm{MPa})$ & 20 & 15 \\
Erime sicaklığ $\left({ }^{\circ} \mathrm{C}\right)$ & 120 & 130 \\
Darbe dayanımı $\left(\mathrm{kj} / \mathrm{m}^{2}\right)$ & 5 & 5 \\
\hline
\end{tabular}

\subsection{Penetrasyon Testi}

Penetrasyon deneyi ile bitümün sertliği veya kıvamı tespit edilmektedir. Penetrasyonun kelime anlamı, batma veya içe girme demektir. Standart penetrasyon deneyi, $100 \mathrm{gr}$ ağırlığındaki bir iğnenin $25^{\circ} \mathrm{C}$ sıcaklıkta ve 5 saniye süreyle bitüm içerisinde dikey olarak kat ettiği mesafe olarak tanımlanmaktadır [21]. Numune üzerinde kabın kenarına ve birbirine $1 \mathrm{~cm}$ 'den daha yakın olmayan noktalardan en az 3 deneme alınır ve kabul edilebilir ölçümlerin aritmetik ortalaması numunenin penetrasyon değeri olarak kabul edilir. Penetrasyonun birimi $10^{-1} \mathrm{~mm}$ 'dir. Bitümün penetrasyon değeri kıvamla ters orantılıdır, penetrasyon yükseldikçe bitüm yumuşamaktadır. Bitümün kıvamı arttıkça karışım içerisindeki agregaları birbirine daha kuvvetli şekilde bağlamaktadır.

\subsection{Yumuşama Noktası Testi}

Bitümün yumuşama sıcaklığını tespit etmek amacıyla yapılan bir deneydir. Bu deneyde, bitüm doldurulmuş standart halka düzeneğe yerleştirilmekte ve bitüm üzerine $2,5 \mathrm{~cm}$ yükseklikten standart bir bilye bırakılmaktadır. Deney başlangıç sıcaklığ $5^{\circ} \mathrm{C}$ dir ve deney boyunca sıcaklık dakikada $5^{\circ} \mathrm{C}$ arttırılmaktadır. Yumuşama noktası değeri, bitümlü malzemenin tabana değdiği anda termometrenin gösterdiği değerdi [22]. Yumuşama noktası yüksek bağlayıcının kullanıldığı karışımlarda tekerlek etkisiyle oluşan deformasyonların daha az olduğu görülmektedir. Tekerlek izine hassas karışımlar için yumuşama noktası sıcaklı̆̆ının tekerlek iziyle iyi bir korelasyon sağladığı ve yumuşama noktasındaki $5-6^{\circ} \mathrm{C}$ 'lik bir azalmanın $\% 20$ daha fazla tekerlek izine yol açtığı bilinmektedir.

\subsection{Dönel Viskozite Testi}

Dönel viskozimetre (RV) deneyi, bitümlü bağlayıcıların yüksek sıcaklıktaki akışkanlık karakteristiklerini belirlemek amacıyla uygulanmaktadır. Bu amaçla AASHTO T316 standardına uygun olarak "Brookfield 
Viskozimetresi” kullanılmaktadır [23]. Bağlayıcıların yüksek sıcaklık viskozite değerleri, pompalanma ve karıştırma sırasında bağlayıcıların yeterince akışkan olduklarının tespiti amacıyla belirlenmektedir. Deneyde bir motor yardımıyla milin düzenli olarak 20 devir/dakika hızla dönmesi sağlanmakta ve viskozite okumaları yapılmaktadır. Genellikle orijinal bağlayıcılar üzerinde uygulanan RV deneyinde $135^{\circ} \mathrm{C}$ 'deki viskozite değerinin 3 Pa.s'yi aşmaması istenir. Bitümlü bağlayıcıların viskozite değerleri ASTM D4402 standardına göre belirlenmiştir.

\section{Deneysel Sonuçlar}

\subsection{Penetrasyon Deney Sonuçları}

Saf ve modifiye edilmiş bağlayıcılara uygulanan penetrasyon deneylerinden elde edilen sonuçlar Şekil 2'de verilmiştir.

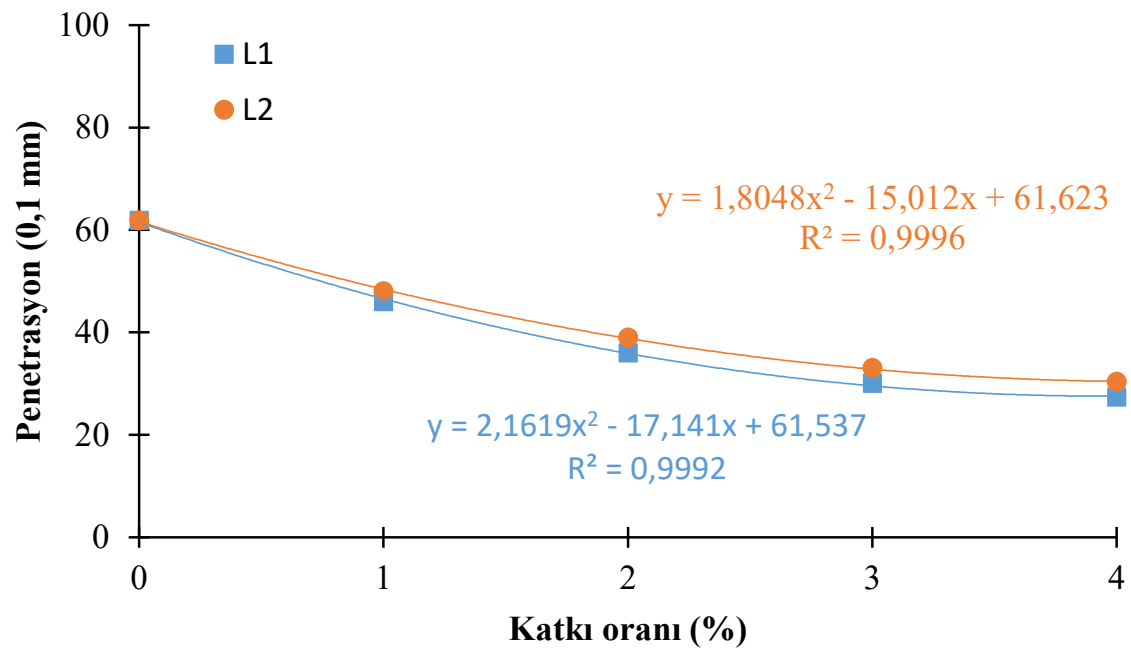

Şekil 2. Penetrasyon değerlerindeki değişiklik

L1 ve L2 modifiyeli bitümlerin penetrasyon değerleri, katk1 içeriğinin artmasıyla polinom olarak azalmaktadır. L1-4 ve L2-4 bağlayıcılarının saf bağlayıcıya kıyasla penetrasyon değerinde önemli bir azalma görülmemiştir. L1 modifiyeli bitüm, L2 modifiyeli bitüm ile yakın penetrasyon değerlerine sahiptir. Ancak bu iki modifiyeli bitümden L1 modifiyeli bitüm daha düşük penetrasyon değerine sahiptirler. L1-4 ve L2-4 modifiye bağlayıcılarının penetrasyon değerleri saf bağlayıcıya göre sırasıyla \%55,8 ve \%51 azalmıştır. L1-1 ve L2-1 modifiye bağlayıcılarının penetrasyon değerleri ise saf bağlayıcıya göre sırasıyla \%25,6 ve \%22,3 azalmıştır.

\subsection{Yumuşama Noktası Deney Sonuçları}

Saf ve modifiye bitümlü bağlayıcılara uygulanan yumuşama noktası deneylerinden elde edilen sonuçlar, Şekil 3 'te verilmiştir. Yumuşama noktası değerleri ile L1 ve L2 içeriği arasında doğrusal bir ilişki vardır. \%1 ve $\% 2$ katk1 içeriğinde hem L1 hem de L2 modifikasyonu yaklaşık benzer yumuşama noktası değerleri vermektedir. $\% 3$ ve \%4 katkı içeriklerinde L1 ve L2 modifikasyonlarının yumuşama noktası değerleri farklılık göstermektedir. L1 katkısının bitüme $\% 1, \% 2, \% 3$ ve $\% 4$ oranlarında ilave edilmesi ile yumuşama noktası değerleri saf bağlayıcıya göre sirasıly $\% 5,9 ; \% 10,7 ; \% 16,3$ ve $\% 20,5$ oranlarında artmıştır. L2 katkısının bitüme $\% 1, \% 2, \% 3$ ve $\% 4$ oranlarında ilave edilmesi ile yumuşama noktası değerleri saf bağlayıcıya göre sırasıyla \%5,1; \%9,2; \%12,2 ve \%13,9 oranlarında artmıştır. L1 modifikasyonunda yumuşama noktasındaki değişiklik L2 modifikasyonundan daha belirgindir. Her iki katkı maddesinin de kullanıldığı sıcak karışım asfaltın yüksek sıcaklık direncine katkıda bulunabileceği açıktır. Ancak, kalıcı deformasyon açısından L1 modifikasyonu ile aynı performansını sağlamak için L2 katkısının L1 katkısından daha yüksek oranlarda kullanılması gerekmektedir. 


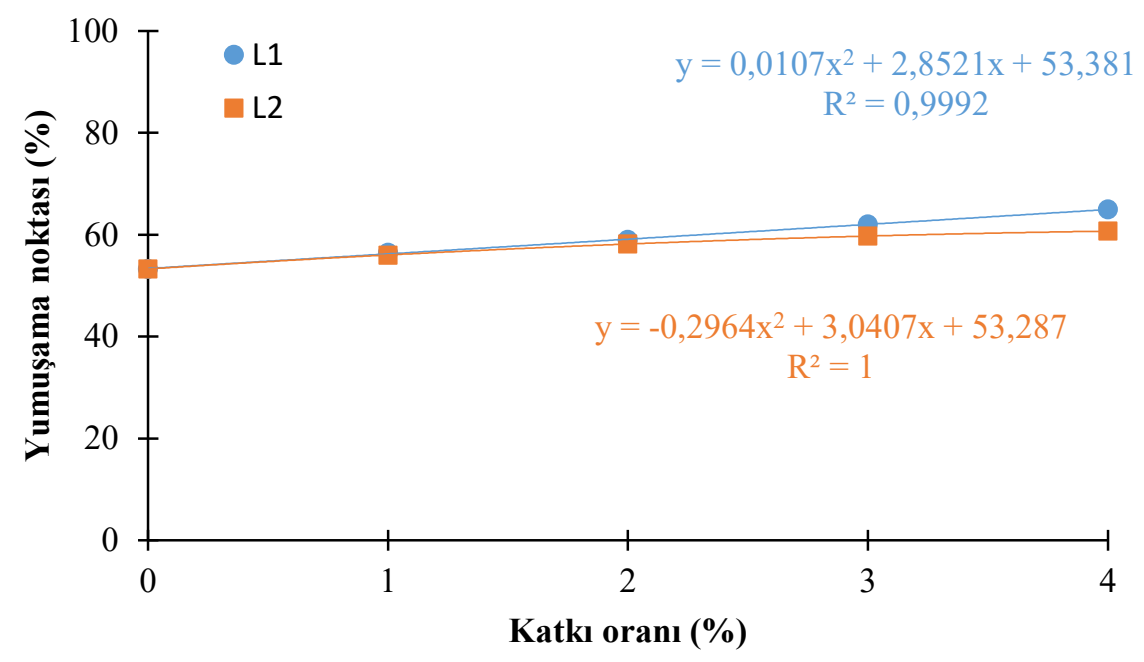

Şekil 3. Yumuşama noktası değerlerindeki değişiklik

Penetrasyon ve yumuşama noktası deneyleri, bağlayıcının kıvamını belirlemekte ve sınıflandırılmasını sağlamaktadır. Bitümlü bağlayıcılar termoplastik olduğundan, düşük sıcaklıklarda sert, yüksek sıcaklıklarda ise daha yumuşak özellik göstermektedir. Bu özellik 1sıya duyarlılık olarak bilinir ve bağlayıcının en önemli özelliklerinden biridir. Penetrasyon ve yumuşama noktası değerleri kullanılarak ısıya karşı hassasiyeti ifade eden penetrasyon indeksi (PI) değerleri Denklem 1 ve 2 kullanılarak hesaplanmıştır [2]. Belirli bir bitümün penetrasyon indeksini bilmek, bir uygulamadaki davranışını tahmin etmeyi sağlar.

$$
\begin{aligned}
& \mathrm{A}=\left(\log \mathrm{P}_{25}-\log 800\right) /\left(25-\mathrm{T}_{\mathrm{YN}}\right) \\
& \mathrm{PI}=(20-500 \mathrm{~A}) /(1+50 \mathrm{~A})
\end{aligned}
$$

Denklem 1 ve 2 'de $\mathrm{P}_{25}, 25^{\circ} \mathrm{C}$ sıcaklıkta yapılan standart penetrasyon değerini, $\mathrm{T}_{\mathrm{YN}}$ ise yumuşama noktası (halka bilye metodu) değerini ifade etmektedir. PI değeri ile 1sıya karşı hassasiyet arasında ters orantı bulunmaktadır. PI değeri arttıkça ısıya karşı hassasiyet azalmaktadır. Bağlayıcıların PI değerleri Şekil 4'te ve Şekil 5 'te verilmiştir.

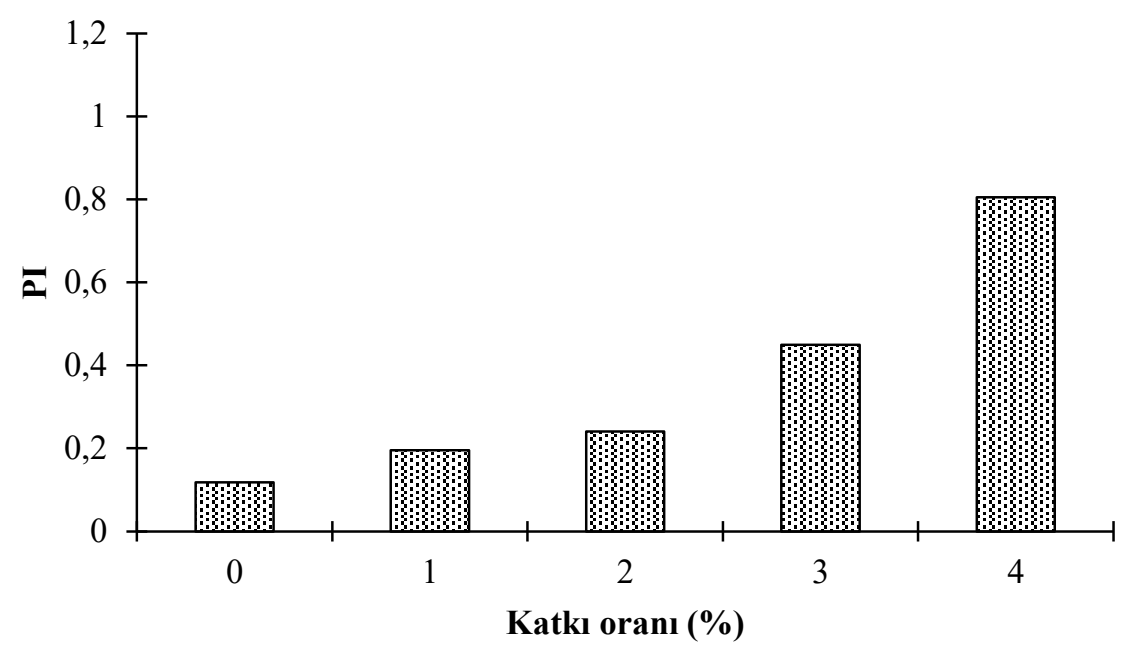

Şekil 4. L1 bağlayıcısının PI değerleri 


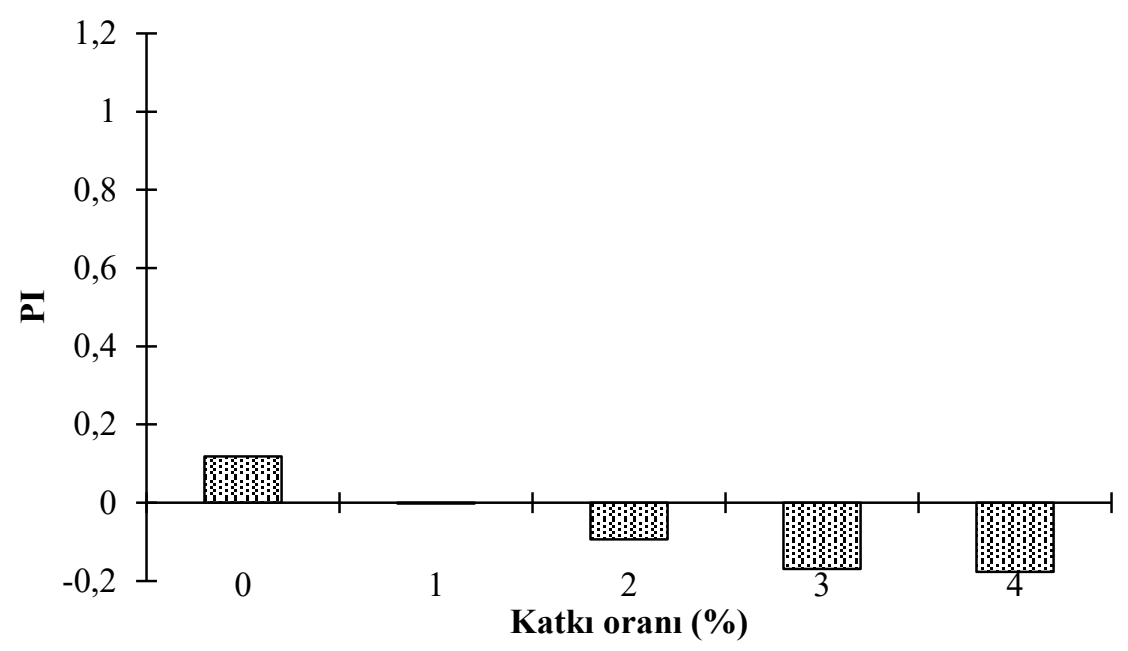

Şekil 5. L2 bağlayıcısının PI değerleri

L1-4 bağlayıcısı en yüksek PI değerini vermektedir. L1 katkı içeriği arttıkça PI değerleri de artmaktadır. $\% 3$ ve $\% 4$ katkı içeriklerinde PI değerinde önemli bir artış gözlenmektedir. L1 katkısının bitüme \%1, \%2, \%3 ve \%4 oranlarında ilave edilmesi ile PI değerleri saf bağlayıcıya göre sırasıyla 1,65;2,03; 3,79 ve 6,79 kat artmıştır. L1 katkısının 1sıya duyarlılık üzerinde olumsuz bir etkisinin olmadığ 1 görülmektedir. L1 modifikasyonunun bütün katkı içeriklerinde PI değerleri +1 değerinin üzerine çıkmamaktadır. En düşük PI değerini ise \%4 katkı içeriğine sahip L2 modifiyeli bitüm vermektedir. L2 modifikasyonunun PI değerleri -1 değerinin üzerine çıkmaktadır. Katk1 içeriği arttıkça L2 modifikasyonunun PI değerlerinde azalma meydana gelmektedir. Isıya karşı bağlayıcıların hassasiyetini ifade eden PI değerlerinden, bağlayıcı sertliği arttıkça PI değerinin de arttığı dolayısıyla 1sıya karşı hassasiyetin azaldığı belirlenmiştir.

\subsubsection{Dönel Viskozimetre Deneyi}

$135^{\circ} \mathrm{C}$ ve $165^{\circ} \mathrm{C}$ 'deki saf ve modifiye edilmiş bağlayıcıların viskoziteleri üzerindeki değişim sırasıyla Şekil 6 ve Şekil $7^{\prime}$ de verilmektedir.

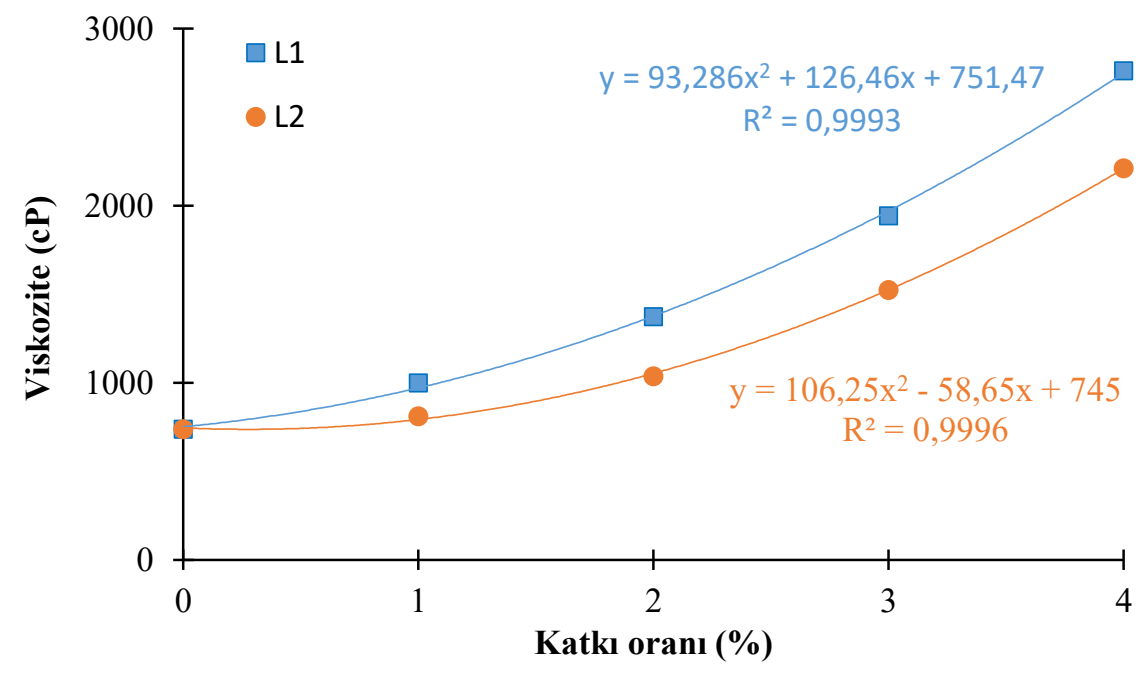

Şekil 6. Bağlayıcıların $135^{\circ} \mathrm{C}$ deki viskozite değerleri 


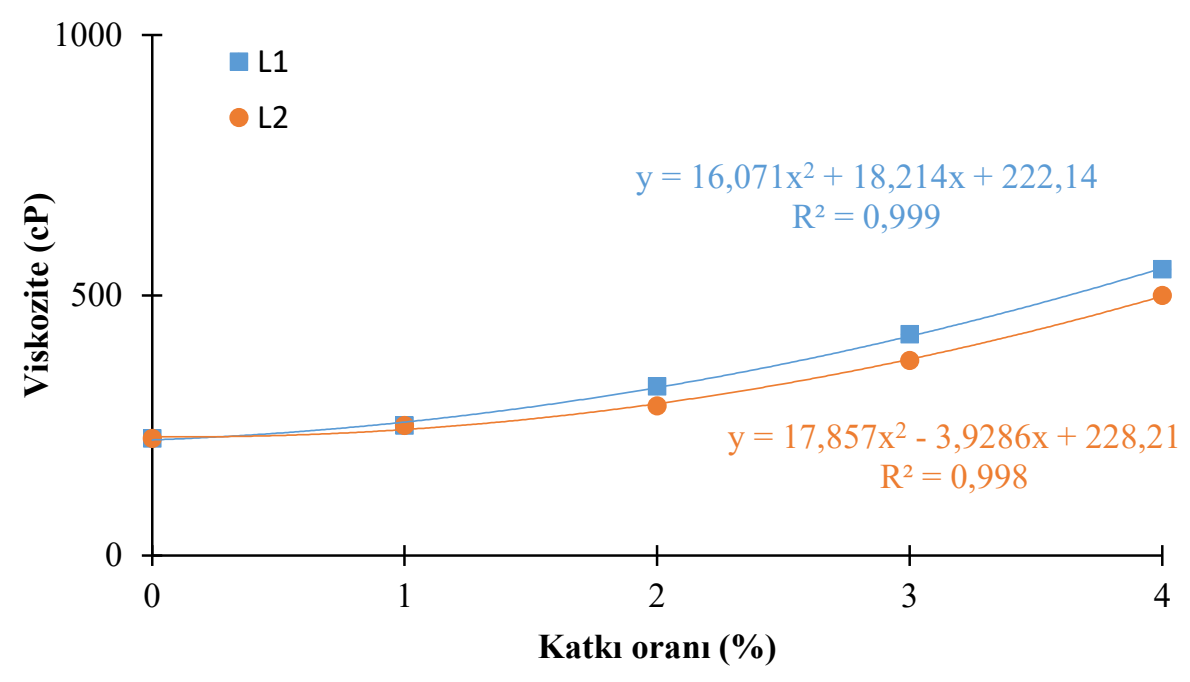

Şekil 7. Bağlayıcıların $165^{\circ} \mathrm{C}$ deki viskozite değerleri

L1 ve L2 modifiye bitümlerinin katkı içeriği arttıkça hem $135^{\circ} \mathrm{C}$ hem de $165^{\circ} \mathrm{C}$ sıcaklıktaki viskozite değerlerinde polinom artışı gözlenmektedir. Bununla birlikte, $135^{\circ} \mathrm{C}$ 'de en yüksek L1 içeriğinde bile 3 Pa.s viskozite değerinin aşılmamasından dolayı herhangi bir işlenebilirlik sorunu yoktur. Viskozite eğilimindeki değişimin $135^{\circ} \mathrm{C}$ ve $165^{\circ} \mathrm{C}$ için benzer olduğu görülmektedir. Fakat $135^{\circ} \mathrm{C}^{\prime}$ ye göre $165^{\circ} \mathrm{C}$ 'de L1 ve L2 modifikasyonlu bağlayıcılar yaklaşık benzer viskozite değerleri vermektedir. $165^{\circ} \mathrm{C}$ de $\% 1$ katkı içeriğinde L1 ve L2 modifikasyonu neredeyse aynı viskozite değerine sahiptir. Ancak \%1 katk1 içeriğinden sonra katkı içeriği arttıç̧ L1 ve L2 modifikasyonları daha farklı viskozite değerlerine sahiptir. \%1, \%2, \%3 ve \%4 oranlarında L1 modifiye bitümleri, $135^{\circ} \mathrm{C}^{\prime}$ deki saf bitüm ile karşılaştırıldığında sırasıyla 1,$36 ; 1,86 ; 2,64$ ve 3,75 kat daha yüksek viskozite değerleri vermektedir. $165^{\circ} \mathrm{C}$ 'de ise sırasıyla saf bağlayıcıya göre 1,$11 ; 1,44 ; 1,89$ ve 2,44 kat daha yüksek viskozite değerleri vermektedir. L1-4 bağlayıcısı en yüksek viskozite değerine sahiptir. $\% 1, \% 2, \% 3$ ve $\% 4$ oranlarında L2 modifiye bitümleri, $135^{\circ} \mathrm{C}^{\prime}$ deki saf bitüm ile karşılaştırıldığında ise sırasıyla 1,$10 ; 1,41 ; 2,07$ ve 3,00 kat daha yüksek viskozite değerleri vermektedir. L2 bağlayıcısı $165^{\circ} \mathrm{C}$ 'de ise katk1 içeriklerine göre sırasıyla saf bağlayıcıya göre 1,11;1,28; 1,67 ve 2,22 kat daha yüksek viskozite değerleri vermektedir. L1 modifiye bağlayıcısının L2 modifiye bağlayıcısına göre tüm katkı içeriklerinde daha yüksek viskozite değerlerine sahip olduğu belirlenmiştir.

\section{Sonuç ve Değerlendirme}

Çalışmada Batman TÜPRAŞ rafinerisinden temin edilen B 50/70 sınıfı bitüme 4 farklı oranda (\%1, \%2, \%3 ve \%4) 2 farklı kimyasal bileşene sahip düşük yoğunluklu polietilen (LDPE) ilave edilerek modifiye bitümler elde edilmiştir. Bağlayıcılar üzerinde penetrasyon, yumuşama noktası ve dönel viskozite deneyleri uygulanarak saf ve modifiye bitümlerin geleneksel özellikleri karşılaştırılmıştır. Yapılan deneylerden aşağıdaki sonuçlar çıkarılabilir:

- L1 ve L2 modifiyeli bitümlerin penetrasyon değerleri, katkı içeriğinin artmasıyla polinom olarak azalmaktadır. L1 ve L2 modifiyeli bağlayıcıların penetrasyon değerleri birbirlerine yakındır. Fakat L1 modifiyeli bitümler L2 modifiyeli bitümlere göre daha düşük penetrasyon değerine sahiptir. Ayrıca katkı içeriği arttıkça her iki LDPE katkısı için de penetrasyon değerleri azalmaktadır.

- LDPE modifikasyonunun yumuşama noktası değerleri üzerinde önemli bir etkisi vardır. LDPE içeriğinin artmasıyla yumuşama noktaları istikrarlı bir şekilde artmaktadır. $\% 1$ ve $\% 2$ katkı içeriğinde hem L1 hem de L2 modifikasyonlu bağlayıcılar yaklaşık benzer yumuşama noktası değeri vermektedir. $\% 2$ katkı içeriğinden sonra L1 ve L2 modifikasyonlarının yumuşama noktası değerleri farklılık göstermektedir. İki katkı maddesinin de ilave edildiği sıcak karışım asfaltların yüksek sıcaklık direncine katkıda bulunabileceği açıktır.

- LDPE katkılarının ısı hassasiyetine herhangi bir olumsuz etkisi yoktur. L1 içerikli bağlayıcıların PI değerleri 0 değerinin üzerinde iken L2 içerikli bağlayıcıların PI değerleri 0 değerinin altındadır. 
- $\quad$ L1 ve L2 içeriklerinin artmasıyla viskozite değerleri önemli ölçüde artmaktadır. Ancak en yüksek LDPE içeriğinde bile işlenebilirlik sorunu yoktur. L1 modifiyeli bağlayıcıların L2 modifiyeli bağlayıcılara göre tüm katkı içeriklerinde daha yüksek viskozite değerlerine sahip olduğu belirlenmiştir. Katkı içeriği arttıkça viskozite değerleri de artmaktadır.

$\mathrm{Bu}$ çalışmada, mühendislik performansı, maliyet faydaları ve çevresel etkinin azaltılması açısından asfalt kaplama için çeşitli geri dönüştürülmüş plastiklerin fizibilitesini sistematik bir şekilde birleştirmek, değerlendirmek için bitüm modifikasyonunda LDPE kullanılmıştır.

\section{Kaynaklar}

[1] Ragaert K, Delva L, Geem KV. Mechanical and chemical recycling of solid plastic waste. Waste Manag., 2017; 69: 24-58. https://doi.org/10.1016/j.wasman.2017.07.044.

[2] Chin C, Damen P. Viability of Using Recycled Plastics in Asphalt and Sprayed Sealing Applications. Austroads Publication, 2019; No. AP-T351-19.

[3] Chen Y, Cui Z, Cui X, Liu W, Wang X, Li X, Li S. Life cycle assessment of end-of-life treatments of waste plastics in China. Resour. Conserv. Recycl., 2019a; 146: 348e-57. https://doi.org/10.1016/j.resconrec.2019.03.011.

[4] Jambeck J.R, Geyer R, Wilcox C, Siegler T.R, Perryman M, Andrady A, Narayan R, Law KL. Marine pollution. Plastic waste inputs from land into the ocean. Science; 2015; 347: 768-771.

[5] Filho W.L, Saari U, Fedoruk M, Iital A, Moora H, Kloga M, Voronova V. An overview of the problems posed by plastic products and the role of extended producer responsibility in Europe. J. Clean. Prod., 2019; 214: 550-558. https://doi.org/ 10.1016/j.jclepro.2018.12.256.

[6] He P, Chen L, Shao L, Zhang H, Lu Municipal F. Solid waste (MSW) landfill: a source of microplastics, Evidence of microplastics in landfill leachate. Water Res, 2019; 159: 38-45. https://doi.org/10.1016/j.watres.2019.04.060.

[7] Hwang J, Choi D, Han S, Choi J, Hong J. An assessment of the toxicity of polypropylene microplastics in human derived cells. Sci. Total Environ, 2019; 684: 657-669. https://doi.org/10.1016/j.scitotenv.2019.05.071.

[8] Huang Y, Bird R.N, Heidrich O, A review of the use of recycled solid waste materials in asphalt pavements. Resour. Conserv. Recycl., 2007; 52 (1): 58-73. https:// doi.org/10.1016/j.resconrec.2007.02.002.

[9] Ingrassiaa L.P, Lu X, Ferrotti G, Canestrari F. Renewable materials in bituminous binders and mixtures: speculative pretext or reliable opportunity. Resour. Conserv. Recycl., 2019; 144: 209-222. https://doi.org/10.1016/j.resconrec.2019.01.034.

[10] Khoo H.H. LCA of plastic waste recovery into recycled materials, energy and fuels in Singapore. Resour. Conserv. Recycl., 2019; 145: 67-77. https://doi.org/10.1016/j.resconrec.2019.02.010.

[11] Cockburn H. India Bans Imports of Waste Plastic to Tackle Environmental Crisis. https://www.independent.co.uk/environment/india-plastic-waste-banrecycling-uk-china-a8811696. 2019; html/ (accessed on 20 November 2019).

[12] Walker T.R, Xanthos D. A call for Canada to move toward zero plastic waste by reducing and recycling single-use plastics. Resour. Conserv. Recycl., 2018; 133: 99-100. https://doi.org/10.1016/j.resconrec.2018.02.014.

[13] Keskisaari A, Karki T. The use of waste materials in wood-plastic composites and their impact on the profitability of the product. Resour. Conserv. Recycl.,2018; 134: 257-261. https://doi.org/10.1016/j.resconrec.2018.03.023.

[14] Meng Y, Ling T, Mo KH. Recycling of wastes for value-added applications in concrete blocks: an overview. Resour. Conserv. Recycl., 2018; 138: 298-312. https://doi.org/10.1016/j.resconrec.2018.07.029.

[15] Ramli M, Tabassi A.K. Effects of different curing regimes on engineering properties of polymer-modified mortar. J. Mater. Civ. Eng., 2012; 24 (4): 468-478. https://doi.org/10.1061/(ASCE)MT.1943-5533.0000394.

[16] Makria C, Hahladakisb J.N, Gidarakos E. Use and assessment of "e-plastics" as recycled aggregates in cement mortar. J. Hazard Mater., 2019; 379: 120776. https:// doi.org/10.1016/j.jhazmat.2019.120776.

[17] Arulrajah A, Yaghoubi E, Wong Y.C, Horpibulsuk S. Recycled plastic granules and demolition wastes as construction materials: resilient moduli and strength characteristics. Construct. Build. Mater., 2017; 147: 639-647. https://doi.org/ 10.1016/j.conbuildmat.2017.04.178.

[18] Poulikakos et al. Harvesting the unexplored potential of European waste materials for road construction. Resour. Conserv. Recycl., 2017; 116: 32-44. https://doi.org/10.1016/j.resconrec.2016.09.008.

[19] Sabina K.T.A, Sharma D.K.S, Sharma D.K. Effect of waste polymer modifier on the properties of bituminous concrete mixes. Construct. Build. Mater., 2011; 25(10): 3841-3848. https://doi.org/10.1016/j.conbuildmat.2011.04.003.

[20] Shenghua W, Luke M. Repurposing waste plastics into cleaner asphalt pavement materials: A critical literature review. Journal of Cleaner Production, 2021; 280: 124355

[21] EN 1426. "Bitüm ve Bitümlü Bağlayıcılar-Ĭğne Batma Derinliği Tayini”, Türk Standartları Enstitüsü, Ankara 2015.

[22] TS EN-1427, Bitüm ve bitümlü bağlayıcılar-Yumuşama noktası tayini-Halka ve bilye yöntemi, Türk Standartları Enstitüsü, Ankara, Türkiye, 2015.

[23] AASHTO T 316, Standard Method of Test for Viscosity Determination of Asphalt Binder Using Rotational Viscometer, AASHTO, USA, 2019. 